\title{
Особливості діагностики та хірургічного лікування внутрішньопротокових новоутворень грудної залози
}

У статті проведено аналіз і популяризацію власного досвіду оптимізації діагностики та хірургічного лікування внутрішньопротокових новоутворень грудної залози з комбінованим використанням променевих іендоскопічних методик. 158 клінічних спостережень розділено на дві групи: у контрольній $(n=81)$ використовували традиційні методики діагностики та хірургічного лікування, в основній $(n=77)$ - власні способи селективної галактодуктографії під ендоскопічним контролем, стереотаксичної трепан-біопсії під контролем рентгенівської дуктографії, подвійного ендоскопічно та ехографічно контрольованого маркування зі встановленням особливостей артеріального кровопостачання ареоли. Показано, що послідовне поєднане використання відомих і розроблених методик відповідно до представленого алгоритму забезпечує істотне (з 97,5 до 6,5\%) зменшення сегмента більш травматичних оперативних втручань - центральних дуктектомій, помітне (з 41,0 до 34, 0 хв) скорочення тривалості операцій, статистично значуще $(p<0,05)\left(\right.$ ( 4 45, 4 до 23, 8 см ${ }^{3}$ ) зменшення обсягу видалених тканин, достовірне $(p<0,05)$ (з 11, до д,9\%) зниження частоти післяопераційних ускладнень і скорочення термінів госпіталізації на 3,4 ліжко-дня.

Ключові слова: внутрішньопротокові новоутворення грудної залози, діагностика, хірургічне лікування.

\section{Вступ}

Рак грудної залози (РГЗ) стабільно посідає перше місце у структурі онкологічної патології у жінок України. Серед 10 основних нозологічних форм злоякісних новоутворень його частка становить $23,2 \%$, що перевищує питому вагу раку матки і яєчника разом взятих (National Cancer Institute of Ukraine, 2017).

Розгортання масового скринінгу, збільшення кількості променевих досліджень грудної залози (ГЗ) сприяє виявленню РГЗ на ранніх стадіях, коли можливе проведення органозберігаючих втручань, що значно поліпшує якість життя пацієнток (Смоланка I.I. та співавт., 2014).

Водночас існують форми РГЗ, що не мають пальпаторних або променевих ознак і проявляються лише патологічними виділеннями з соска (ПВС). Втім ПВС виявляють і при інших внутрішньопротокових новоутвореннях (ВПНУ), наприклад папіломі, протоковій гіперплазії, карциномі in situ тощо (Dupont S.C. et al., 2015; Castellano I. et al., 2017). Ця етіологічна неоднорідність ВПНУ значно утруднює планування і проведення хірургічних втручань у зв'язку з неможливістю впевненої передопераційної патогістологічної верифікації (ПГВ) за допомогою прицільних трепан-біопсій (ТБ) при негативних результатах рентгеномамо- (РМГ) та/чи ехографії (ЕГ), які відмічають із частотою $38,1-85,0$ та 34,5-71,0\% відповідно (Colombo P.E. et al., 2014; Hartmann L.C. et al., 2015).

Висока $(18,0-19,3 \%)$ ймовірність ракової неоплазії, особливо у жінок пре- і менопаузального віку, певною мірою виправдовує проведення рутинної дуктектомії (РДЕ), яка по суті є відкритою біопсією, але при цьому порушуються принципи сучасних підходів до «раннього» РГЗ (Жигулін А.В. та співавт., 2016; Cil T.D., McCready D., 2018).

РДЕ, якою вона є сьогодні, характеризується низкою таких недоліків, як необхідність термінового патогістологічного дослідження свіжозамороженого біоптату і перевирізання при виявленні РГЗ у 18,0-20,0\% випадків, утрудненням інтраопераційного пошуку дрібних за розмірами ВПНУ, частим (до 25,4\%) залишенням їх за межами резекції, невиправдано великим обсягом видалених тканин, нерідко (до 16,0\%) ішемічно-некротичними ускладненнями з боку ареолярно-соскового комплексу (АСК) тощо (Chevrot A. et al., 2017).

Зазначені недоліки РДЕ здебільше зумовлені «сліпим» маркуванням сецернуючих молочних проток (СМП), при якому ймовір- ність некерованого попадання маркерів до тих відгалужень, що не містять ВПНУ, становить не менше $50,0 \%$ (Чешук В.Є., Анікусько М.Ф., 2014).

Прицільне ендоскопічно контрольоване маркування полегшує інтраопераційний пошук малих за розмірами ВПНУ і сприяє їхньому адекватному вирізанню з мінімальним обсягом прилеглих тканин, але у 16,3-22,7\% випадків ендоскопічна мамодуктоскопія (ЕМДС) виявляється неспроможною внаслідок анатомічних особливостей та патологічних змін соска та/чи СМП, а також при периферичному розміщенні патологічних осередків у протоках малого калібру (Han Y. et al., 2017; Yuan Z. et al., 2017).

До того ж при маркуванні поодиноким дротиком не виключається можливість неправильної установки, зміщення, випадання маркера чи пошкодження його у процесі операції (Xu Z. et al., 2015; Yilmaz R. et al., 2017).

Отже, на поточний період планування і проведення хірургічних втручань у пацієнтів із ВПНУ ГЗ не є досконалим і потребує оптимізації шляхом розширення можливостей передопераційної ПГВ ендоскопічно недосяжних рентген- і ехонегативних (РіЕН) ВПнУ, об'єктивізації вибору типу і топографії хірургічного розрізу, забезпечення прицільного і малотравматичного видалення патологічних осередків, мінімізації післяопераційних ускладнень.

Мета - аналіз і представлення власного досвіду оптимізації діагностики і хірургічного лікування пацієнтів із ВПНУ ГЗ шляхом поєднаного використання променевих і ендоскопічних методик.

\section{Об'єкт і методи дослідження}

Проведення дослідження ухвалено комісією з біоетики при Національному інституті раку МОЗ України (протокол від 09.12.2015 p. № 77) і відповідає принципам Гельсінкської декларації.

Проаналізовано результати 158 хірургічних втручань у пацієнтів із ВПНУ гЗ. Методом сліпої рандомізації сформовано дві групи спостережень - основну і контрольну. В контрольній групі ( $\mathrm{n}=81)$ застосовано відомі методики, в основній $(n=77)-$ розроблено способи ендоскопічно контрольованої селективної галактодуктографії (ГДГ), стереотаксичної ТБ, передопераційного ехо- і ендоскопічно контрольованого маркування ВПНУ з визначенням індивідуальних особливостей артеріального кровопостачання АCK. 
Спосіб ендоскопічно контрольованої селективної Гдг (патент України № 106064) передбачає проведення ЕМДС, виявлення ендоскопічно недосяжного відгалуження СМП, катетеризацію його гнучким капіляром, введення контрастної речовини і виконання рентгенівських знімків (Аксьонов О.А. та співавт., 2016).

Спосіб стереотаксичної ТБ рентгенонегативних ВПНУ (патент України № 119847) включає традиційну чи селективну ГДГ і при позитивних результатах спрямування пункційної голки або безпосередньо в дефект наповнення, або на 0,1 см проксимальніше від лінії «ампутації» (Білоненко Г.А. та співавт., 2017).

Спосіб передопераційного ехо- і ендоскопічно контрольованого маркування ВПНУ з визначенням особливостей артеріального кровопостачання АСК (патент України № 116603) передбачає проведення ЕМДС, подвійне маркування ВПНУ, обчислення відстані між маркерами, сканування зони передбачуваного хірургічного розрізу в режимі кольорового допплерівського картування, виявлення гілок артеріальних судин та планування типу і топографії хірургічного розрізу залежно від отриманих даних (Аксьонов О.А. та співавт., 2017).

Рентгенологічні дослідження проводили на цифрових мамографічних комплексах «Mammomat 3000 Nova» (Німеччина) та «Hologic M-4» (США), укомплектованих стереотаксичними пункційними приставками.

Для ЕГ використовували сучасні багатофункціональні системи «EnVisor» (Нідерланди), «Prosound-6» (Японія), «Aplio SSA780A» (Японія) з високочастотними (7,0-14,0 МГц) лінійними датчиками.

Результати РМГ і ЕГ оцінювали за категоріями BI-RADS ${ }^{\mathrm{m}}$

ЕМДС проводили 2-канальним дуктоскопом «Karl Storz» (Hiмеччина) з тубусом довжиною 120 мм і зовнішнім діаметром 1,3 мм. Отримані зображення оцінювали відповідно до рекомендацій Японської асоціації грудної дуктоскопії (Japanese Association of Mammary Ductoscopy). Рідину (фізіологічний розчин), зібрану після ЕМДС, піддавали цитологічному дослідженню (дуктальний лаваж).

ТБ під візуальним контролем виконували автоматичним пістолетом «Magnum» із пункційними голками 14-16G «Bard» (США). Патогістологічні дослідження (референтний метод) проводили шляхом світлової мікроскопії препаратів, фарбованих гематоксиліном, еозином і пікрофуксином за ван Гізоном. За потреби застосовували імуногістохімічні реакції.

Статистичну обробку отриманих даних виконано з використанням комп'ютерних програм пакета STATISTICA (StatSoft Statistica v.8.0). Порівняння питомої ваги якісних ознак здійснювали, користуючись критерієм $\chi^{2}$. Статистичну значимість порівнюваних кількісних показників, з розподілом, відмінним від нормального, що визначали за критерієм згоди Колмогорова - Смирнова, встановлювали з використанням U-тесту за методом Манна - Уїтні, при значущості 0,05. Аналізовані дані представлені як «середнє \pm стандартне відхилення» $(\mathrm{M} \pm \mathrm{s})$. Показники діагностичної ефективності розраховували за стандартними формулами

\section{Результати та їх обговорення}

Встановлено часті негативні результати РМГ $(81,3 \%)$ і ЕГ $(68,3 \%)$ та відповідно їх низьку $(19,1-30,8 \%)$ діагностичну чутливість (табл. 1). 3 урахуванням рекомендацій Американської колегії радіології (Lee S.J. et al., 2017) щодо проведення візуально контрольованих ТБ виключно при мамо- і ехографічних зображеннях категорій BI-RADS ${ }^{\text {TM }}$-4-5 нами проведено тільки 6 рентгента 4 ехоконтрольованих ТБ, що становить лише 5,7\% від 158 спостережень, включених у матеріали роботи.

Отже, роль РМГ/ЕГ, в плані як встановлення показань/протипоказань до оперативного втручання, так і використання їх результатів для навігації ТБ, є мінімальною, що повністю зіставне з даними M. Bahl та співавторів (2017) та S.K. Ahn та співавторів (2018), які також переконалися в обмеженій тактичній значущості зазначених діагностичних методик.

При порівнянні діагностичної ефективності традиційної ГдГ та ЕМДС значущої різниці за вивченими показниками не виявлено (табл. 2). Втім встановлено, що ГДГ має певні переваги щодо передопераційної ПГВ, оскільки після традиційного чи селективного контрастування СМП івиявлення специфічних дуктографічних ознак ВПНУ - ліній «ампутації» або дефектів наповнення виника- ють умови для проведення стереотаксичної ТБ за розробленим способом.

На поточний період технологію стереотаксичної ТБ під дуктографічним контролем впроваджено у 15 спостереженнях, і після ПГВ у 12 пацієнток ідентифіковані внутрішньопротокові папіломи, у 2 - інвазивні карциноми та у 1 - карцинома in situ.

Таким чином, слід прийняти до уваги, що за відсутності ендоскопічних або дуктографічних ознак ВПНУ ГЗ у пацієнток віком $<40$ років і без факторів ризику, наприклад сімейного РГЗ, варто утриматися від оперативного втручання та проводити динамічне спостереження впродовж 2 років.

При цьому через підвищену (в 2,5-5,0 раза) ймовірність РГЗ пацієнткам у пре- і менопаузальний період з негативними результатами як діагностичних методик першої лінії (РМГ/ЕГ), так і додаткових методів діагностики (ГДГ/ЕМДС) слід пропонувати оперативне втручання - відкриту біопсію в обсязі РДЕ.

Для полегшення інтраопераційного пошуку дрібних за розмірами ВПНУ, їх адекватного видалення з мінімальним обсягом прилеглих тканин, профілактики ішемічно-некротичних ускладнень з боку АСК доцільно використовувати подвійне передопераційне маркування ВПНУ під ендоскопічним та ЕГ-контролем з урахуванням особливостей артеріального кровопостачання АСК.

Таблиця 1. Діагностична ефективність РМГ та ЕГ у пацієнтів із ВПНу ГЗ

\begin{tabular}{lcc}
\hline \multicolumn{1}{c}{ Параметри/методики } & РМГ $(\mathbf{n}=\mathbf{6 4})$ & ЕГ (n=82) \\
\hline Результати, абсолютне число (\%) & & \\
• істинно позитивні & $9(14,1)$ & $16(19,5)$ \\
- істинно негативні & $14(21,9)$ & $20(24,4)$ \\
- хибнопозитивні & $3(4,7)$ & $10(12,2)$ \\
- хибнонегативні & $38(59,4)$ & $36(43,9)$ \\
Показники, \% & & \\
- чутливість & 19,1 & 30,8 \\
• специфічність & 82,4 & 66,7 \\
- точність & 35,9 & 43,9 \\
\hline
\end{tabular}

Таблиця 2. Діагностична ефективність ГДГ та ЕМДС у пацієнтів із ВПНУ ГЗ

\begin{tabular}{lcc}
\multicolumn{1}{r}{ Параметри/методики } & ГДГ (n=54) & ЕМДС (n=158) \\
\hline Результати, абсолютне число (\%) & $29(53,7)$ & $98(62,1)$ \\
- істинно позитивні & $7(13,0)$ & $16(10,1)$ \\
- істинно негативні & $14(25,9)$ & $34(21,5)$ \\
- хибнопозитивні & $4(7,4)$ & $10(6,3)$ \\
- хиббонегативні & & \\
Показник, \% & 87,9 & 90,7 \\
- чутливість & 33,3 & 32,0 \\
- специфічність & 66,7 & 72,2 \\
- точність & & \\
\hline
\end{tabular}

Таблиця 3. Ефективність хірургічних втручань у хворих основної та контрольної груп

\begin{tabular}{lcc}
\hline \multirow{2}{*}{ Показник } & \multicolumn{2}{c}{ Група } \\
\cline { 2 - 3 } & $\begin{array}{c}\text { основна } \\
\text { (n=77) }\end{array}$ & $\begin{array}{c}\text { контрольна } \\
\text { (n=81) }\end{array}$ \\
Характер операцій, абсолютне число (\%) & & \\
• центральна дуктектомія $(p<0,001)$ & $5(6,5)$ & $79(97,5)$ \\
- селективна дуктектомія (p<0,001) & $72(93,5)$ & $2(2,5)$ \\
Тип хірургічного розрізу, абсолютне число (\%) & & \\
- періареолярний & $65(85,5)$ & $74(91,4)$ \\
- напівовальний (р<0,05) & $8(10,5)$ & $2(2,5)$ \\
- радіарний & $3(4,0)$ & $5(6,2)$ \\
Тривалість операції, хв & $34,0 \pm 5,0$ & $41,0 \pm 4,0$ \\
Обсяг резекції, см ${ }^{3}(p<0,05)$ & $23,8 \pm 11,9$ & $45,4 \pm 12,8$ \\
Ускладнення, абсолютне число (\%) & $3(3,9)$ & $9(11,1)$ \\
- гематома & $1(1,3)$ & $2(2,5)$ \\
- серома & $2(2,6)$ & $5(6,2)$ \\
- частковий некроз АСК & - & $2(2,5)$ \\
Терміни госпіталізації, діб & $4,5 \pm 1,5$ & $7,9 \pm 1,6$ \\
\hline
\end{tabular}

Таблиця 4. Результати патогістологічних досліджень операційного матеріалу

\begin{tabular}{lcc}
\hline \multicolumn{1}{c}{$\begin{array}{c}\text { Патогістологічні форми, } \\
\text { абсолютне число (\%) }\end{array}$} & \multicolumn{2}{c}{ Група } \\
\cline { 2 - 3 } & $\begin{array}{c}\text { основна } \\
(\mathbf{n = 7 7 )}\end{array}$ & $\begin{array}{c}\text { контрольна } \\
\text { (n=81) }\end{array}$ \\
\hline Множинні папіломи $(\mathbf{p}<0,001)$ & $40(51,9)$ & $12(14,8)$ \\
Солітарні папіломи $(\mathrm{p}<0,001)$ & $30(39,0)$ & $11(13,5)$ \\
Атипова протокова гіперплазія & $5(6,5)$ & $2(2,5)$ \\
Інвазивна карцинома & $2(2,6)$ & $6(7,4)$ \\
Фіброаденомато3 (p<0,001) & - & $40(49,4)$ \\
Запалення (p<0,05) & - & $7(8,6)$ \\
Дуктектазія & - & $3(3,7)$ \\
\hline
\end{tabular}


Переваги цього способу демонструють результати проведених оперативних втручань (табл. 3). Так, при його використанні частіше (на 91,0\%) проводять менш травматичні оперативні втручання - селективні дуктектомії, вірогідно $(p<0,001)$ на 21,6 см³ зменшується обсяг видалених тканин, що сприяє зниженню частоти післяопераційних ускладнень на 7,2\% і вірогідному $(p<0,001)$ скороченню термінів госпіталізації на 3,4 доби.

Також, як свідчать результати патогістологічних досліджень (табл. 4), застосування зазначеного способу сприяє більш аргументованому встановленню показань до оперативного втручання. Так, у 61,7\% хворих контрольної групи патогістологічні діагнози були представлені фіброаденоматозом, дуктектазією та запаленням, тобто патологічними станами, які не $є$ ВПНУ і причинна роль яких при ПВС є сумнівною. Навпаки, у пацієнток основної групи вказані діагнози не спостерігали.

Показово, що у жінок основної групи після подвійного передопераційного ендоскопічно і ехографічно контрольованого маркування ВПНУ з урахуванням індивідуальних особливостей артеріального кровопостачання АСК вірогідно $(p<0,001)$ переважали $(90,9 \%)$ солітарні чи множинні папіломи, які є реальною причиною ПВС і дійсно потребують хірургічного лікування.

Для встановлення оптимальної послідовності поєднаного використання розроблених методик у комплексі з традиційними підходами створено алгоритм, представлений на рисунку. Переваги цієї пропозиції у порівнянні, наприклад, з відомими алгоритмами N. Lipра та співавторів (2015) та Y. Cohen (2016) полягають, перш за все, у застосуванні ЕМДС - єдиної на сьогодні методики, що забезпечує прямий візуальний контакт із ВПНУ, а також в уникненні таких високовартісних технологій, як магнітно-резонансна томографія чи мамографічний томосинтез.

Запропонований алгоритм забезпечує оптимальну структуризацію діагностичних і лікувальних заходів у пацієнтів із ВПНУ ГЗ, що виключає можливість безпідставного призначення зайвих, дублюючих досліджень, об'єктивізує встановлення показань до оперативного втручання, дозволяє уникнути непотрібних операцій

\section{Висновки}

Рентгенівська ГдГ і ендоскопічна мамодуктоскопія як традиційні методики передопераційної діагностики ВПНУ ГЗ характеризуються недостатньою специфічністю (33,3 та 32,0\% відповідно), що обмежує їх значущість у плануванні та проведенні хірургічних втручань.

Рутинна дуктектомія після «сліпого» перед- або інтраопераційного маркування СМПхарактеризується значним $\left(45,4 \pm 12,8\right.$ см $\left.{ }^{3}\right)$ обсягом видалених тканин, частим $(61,7 \%)$ залишенням ВПНУ за межами резекції, розвитком післяопераційних ускладнень у $11,1 \%$ випадків.

Послідовне поєднане використання відомих і розроблених методик відповідно до представленого алгоритму забезпечує суттєве (з 97,5 до 6,5\%) зменшення частки більш травматичних хірургічних втручань - центральних дуктектомій, помітне (з 41,0 до 34,0 хв) скорочення тривалості операцій, статистично значуще $(p<0,05)($ з 45,4 до 23,8 cм³) зменшення обсягу видалених тканин, вірогідне $(p<0,05)(311,1$ до 3,9\%) зниження частоти ускладнень і скорочення термінів госпіталізації на 3,4 доби.

\section{Список використаної літератури}

Аксьонов О.А., Білоненко Г.А., Аксьонова О.Г. (2017) Пат. 116603 U Україна, МПК (2017.01) A61B 8/00. Спосіб вибору хірургічної тактики при внутрішньопротокових новоутвореннях грудної залози. Винахідники та патентовласники Аксьонов О.А., Білоненко Г.А., Аксьонова О.Г. (UA). № u2016 12959. Заявл. 19.12.2016. Опубл. 25.05.2017. Бюл. № 10: 4 C.

Аксьонов О.А., Смоланка І.І., Білоненко Г.А., Аксьонова О.Г. (2016) Пат. 106064 U Україна, МПК (2016.01) A61B 8/08. Спосіб селективної ендоскопічно контрольованої рентгеногалактодуктографії. Винахідники та патентовласники Аксьонов 0.А., Смоланка І.І., Білоненко Г.А., Аксьонова О.Г. (UA) № u2015 11125. Заявл. 12.11.2015. Опубл. 11.04.2016. Бюл. № 7: 2 с.

Білоненко Г.А., Сєдаков І.Є., Аксьонов О.А. та ін. (2017) Пат. 119847 U Україна, МПК (2006.01) G01N 33/50. Спосіб прицільної стереотаксичної трепан-біопсії рентгенонегативних внутрішньопротокових новоутворень грудної залози. Винахідники та патентовласники Білоненко Г.А., Сєдаков І.Є., Аксьонов О.А., Аксьонова О.Г., Сухіна Н.О., Хлопушин Є.Ю., Старушко Р.В. (UA). № u201704080. Заявл. 24.04.2017. Опубл. 10.10.2017. Бюл. № 19: 4 c.

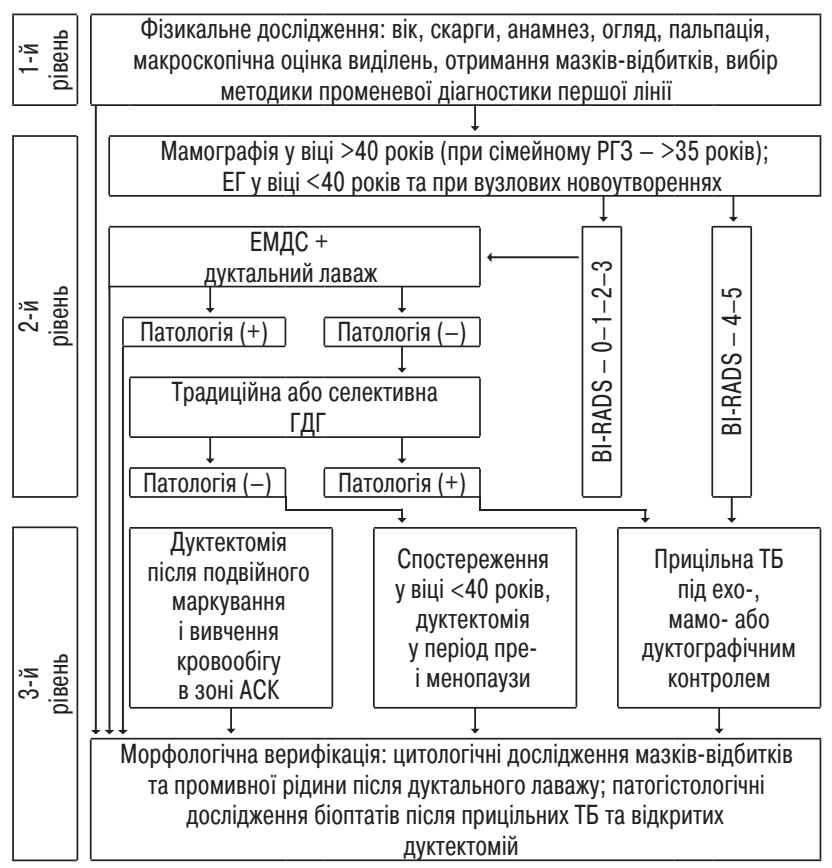

Рисунок. Алгоритм поєднаного використання традиційних і розроблених методик

Жигулін А.В., Палиця В.Я., Дмитренко О.А. та ін. (2016) Онкопластична та реконструктивна хірургія раку грудної залози. Досвід впровадження. Клін. онкологія, 2(22): 19-25.

Смоланка І.І., Скляр С.Ю., Головко Т.С., Ганіч О.В. (2014) Сучасні можливості проведення скрінінгу захворювань грудної залози. Клін. онкологія, 1(13): $32-34$.

Чешук В.Є., Анікусько М.Ф. (2014) Пат. 88345 Україна, МПК (2014.01) A61B 17/00. Спосіб визначення локалізації внутрішньопротокової папіломи молочної залози під час хірургічного лікування. Патентовласник Національний медичний університет ім. 0.0. Богомольця (UA). № u201312183. Заявл. 18.10.2013. Опубл. 11.03.2014. Бюл. № 5: 3 c.

Ahn S.K., Han W., Moon H.G. (2018) Management of benign papilloma without atypia diagnosed at ultrasound-guided core needle biopsy: Scoring system for predicting malignancy. Eur. J. Surg. Oncol., 44(1): 53-58.

Bahl M., Gadd M.A., Lehman C.D. (2017) Diagnostic utility of MRI after negative or inconclusive mammography for the evaluation of pathologic nipple discharge. AJR. Am. J. Roentgenol., 209(6): 1404-1410.

Chevrot A., Pelissier A., Rouzier R. (2017) Papillome mammaire: comment je fais... une pyramidectomie guidée par un fil de crin. Gynecol. Obstet. Fertil. Senol., 45(11): 632-633.

Cil T.D., McCready D. (2018) Modern approaches to the surgical management of malignant breast disease. The role of breast conservation, complete mastectomy, skin- and nipple-sparing mastectomy. Clin. Plast. Surg., 45(1): $1-11$.

Cohen Y. (2016) Conventional ductography combined with digital breast tomosynthesis for imaging of pathologic nipple discharge. AJR Am. J. Roentgenol., 206 (2): W44.

Castellano I., Metovic J., Balmativola D. et al. (2017) The impact of malignant nipple discharge cytology (NDc) in surgical management of breast cancer patients. PLoS One, 12(8): e0182073.

Colombo P.E., Vincent-Salomon A., Chateau M.C. et al. (2014) Breast surgeon role in the management of high-risk breast lesions. Bull. Cancer, 101(7/8): 718-729.

Dupont S.C., Boughey J.C., Jimenez R.E. et al. (2015) Frequency of diagnosis of cancer or high-risk lesion at operation for pathologic nipple discharge. Surgery, 158(4): 988-995.

Han Y., Li J., Han S. et al. (2017) Diagnostic value of endoscopic appearance during ductoscopy in patients with pathological nipple discharge. BMC Cancer, 17(1): 300 .

Hartmann L.C., Degnim A.C., Santen R.J. et al. (2015) Atypical hyperplasia of the breast - risk assessment and management options. N. Engl. J. Med., 372(1): 78-89.

Lee S.J., Trikha S., Moy L. et al. (2017) ACR Appropriateness criteria ${ }^{\circledR}$ evaluation of nipple discharge. J. Am. Coll. Radiol., 14(5S): s138-s153.

Lippa N., Hurtevent-Labrot G., Ferron S., Boisserie-Lacroix M. (2015) Nipple discharge: the role of imaging. Diagn. Interv. Imaging, 96(10): 1017-1032.

National Cancer Institute of Ukraine (2017) Bulletin of national cancer registry of Ukraine (http://www.ncru.inf.ua/publications/BULL_18/index_e.htm). 
Xu Z., Xing W., Li Q. et al. (2015) Assessment of diagnostic and therapeutic value of ductoscopy biopsy in single intraductal papillary lesion compared with open surgery. Cancer Res., 75 (9 suppl.): Abstr. 2-13-10.

Yilmaz R., Bender O., Yabul F.Q. et al. (2017) Diagnosis of nipple discharge: value of magnetic resonance imaging and ultrasonography in comparison with ductoscopy. Balkan Med. J., 34(2): 119-126.

Yuan Z., Qu X., Zhang Z.T., Jiang W.G. (2017) Application of localization and needle placement guided by mammographic, ultrasound and fiberoptic ductoscopy for resection of non-palpable breast lesions. Anticancer Res., 37(8): 45234527

\section{Особенности диагностики и хирургического лечения внутрипротоковых новообразований грудной железы}

\section{И.И. Смоланка, А.А. Аксенов, Е.Г. Аксенова, Г.А. Белоненко}

Резюме. Проведен анализ и популяризация собственнного опыта оптимизации диагностики ихирургического лечения внутрипротоковых новообразований грудной железы с комбинированным использованием лучевыхи эндоскопическихметодик. 158 клиническихнаблюде ний разделены на две группы: в контрольной $(n=81)$ использовали традиционные методики диагностики и хирургического лечения в основной $(n=77)$ - собственные способы селективной галактодуктографии под эндоскопическим контролем, стереотаксической трепан-биопсии под контролем рентгеновской дуктографии, двойной эндоскопически и эхографически контролируемой маркировки с установлением особенностей артериального кровоснабжения ареолы. Показано, что последовательное сочетанное использование известных и разработанных методик в соответствии с представленным алгоритмом обеспечивает существенное (с 97,5 до 6,5\%) уменьшение сегмента более травматичныхоперативныхвмешательств - центральных дуктэктомий, заметное (с 41,0 до 34,0 мин) сокращение продолжительности операций, статистически значимое $(p<0,05)$ (c 45,4

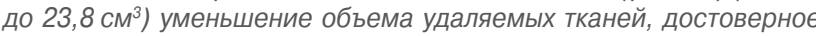
$(p<0,05)(c 11,1$ до 3,9\%) снижение частоты послеоперационных ос ложнений и сокращение сроков госпитализации на 3, 4 койко-дня.
Ключевые слова: внутрипротоковые новообразования грудной железы, диагностика, хирургическое лечение.

\section{Features of diagnosis and surgical treatment of intraductal neoplasms of the breast}

\section{I.I. Smolanka, A.A. Aksenov, E.G. Aksenova, G.A. Belonenko}

Summary. The analysis and popularization of own experience in optimizing the diagnosis and surgical treatment of intraductal neoplasms of the breast with the combined use of radial and endoscopic techniques was conducted. 158 clinical observations are divided into 2 groups: in the control $(n=81)$, traditional methods of diagnosis and surgical treatment were used, in the main $(n=77)$ - own methods of selective galactoctodography under endoscopic control, stereotactic trepan biopsy under the X-ray control, double endoscopically and echographically controlled marking with establishment of the areola arterial blood supply. It was shown that the combined use of known and developed techniques in accordance with the presented algorithm provides a significant (from 97.5 to $6.5 \%$ ) reduction in the segment of more traumatic operations - central ductectomyes, appreciable (from 41.0 to $34.0 \mathrm{~min}$ ) reduction in the duration of operations, statistically significant $(p<0.05)$ (from 45.4 to $\left.23.8 \mathrm{~cm}^{3}\right)$ decrease in the volume of tissues removed, significant $(p<0.05)$ (from 11.1 to $3.9 \%$ ) decrease the frequency of postoperative complications and the reduction in hospitalization by 3.4 days.

Key words: intraductal neoplasms of the breast, diagnosis, surgical treatment.

\section{Адреса для листування:}

Олексій Анатолійович Аксьонов

01021, Київ, Кловський узвіз, 13А

Український науково-практичний центр ендокринної хірургії та трансплантації ендокринних органів і тканин М03 України E-mail: aleax17@ukr.net

Одержано 19.11.2018

\section{РЕФЕРАТИВНА ІНФОРМАЦІЯ}

\section{Описаны генетические маркеры уролитиаза}

Несмотря на наличие доказательств того, что генетические факторы могут играть существенную роль, повышая риск развития мочекаменной болезни (МКБ), генетические предпосылки этого состояния по-прежнему недостаточно ясны. По результатам проведенных исследований общегеномных ассоциаций, идентифицированы 6 генетических локусов, предположительно связанных с риском формирования уролитиаза. В недавней работе ученых Лаборатории геномных технологий Центра генома человека (Human Genome Center) и Токийского университета (University of Tokyo), Япония, описаны новые генетические маркеры, вероятно, оказывающие влияние на риск развития МКБ. По мнению авторов, полученные данные могут быть полезны в прогнозировании риска уролитиаза у детей, а также для поиска новых мишеней профилактики и терапии заболевания.

Известно, что наличие данных о МКБ в семейном анамнезе ассоциируется сповышением рискауказанныхобменныхнарушений в >2 раза. В исследованиях близнецовыхпар установлена наследуемость подобного состояния, достигающая $56 \%$, что свидетельствует об основной роли генетических факторов в формировании патологии. Описаны 6 генетическихвариаций, экспрессия которыхможет создавать предпосылки для развития МКБ. Однако роль этих маркеров не до конца изучена. В представленной работе для идентификации генетических локусов, ассоциированных с изучаемыми обменными нарушениями, исследователи предприняли крупномасштабный анализ общегеномных ассоциаций (Genome-Wide Association Studies - GWAS) в выборке 11130 человекпо сравнению с данными контрольной группы - 187639 участников - с последующим анализом репликации на примере данных 2289 лиц основной группы и 3817 человек группы контроля. Диагноз МКБ подтвержден клинически, а также с использованием медицинских карт или самоотчетов. Также проведена оценка взаимосвязи генетических локу- сов, предположительно ассоциированных с уролитиазом, с 16 количественными признаками, включая метаболические, почечные и электролитные показатели (индекс массы тела, липидный профиль, рецептор эпидермального фактора роста, мочевая кислота и кальций в плазме крови), используя около 160 тыс. образцов из базы БиоБанка Японии.

По итогам проведенного анализа описано 14 значимых локусов, включая 9 новых. 10 из 14 подтвержденных локусов показали высокую степень взаимосвязи по меньшей мере с одним из количественных признаков, включая метаболические, почечные и электролитные показатели, что, по мнению авторов, указывает на общую генетическую основу для МКБ и проанализированных маркеров обмена веществ. 4 локуса также ассоциировались с метаболическими особенностями, метаболическим синдромом, гипертриглицеридемией или гиперурикемией. Вместе с тем 10 локусов генетического контроля демонстрировали взаимосвязь с характеристиками электролитного обмена, определяющими вероятность процессов кристаллизации. В целом по результатам балльной оценки генетического риска установлено, что в группе наибольшего риска (20\%) отношение рисков составляло $1,71-2,13$ по сравнению с контрольной группой $(<20 \%)$.

Проведенная работа является одним из первых крупномасштабных исследований в данной области. Учитывая то, что МКБ относится к числу предотвратимых заболеваний - путем изменения факторов образа жизни, таких как уровень гидратации, контроль массы тела и регуляции диетических предпочтений, результаты исследования достаточно значимы в отношении прогнозирования риска и профилактики развития уролитиаза.

Tanikawa C., Kamatani Y., Terao C. et al. (2019) Novel Risk Loci Identified in a Genome-Wide Association Study of Urolithiasis in a Japanese Population. J. Am. Soc. Nephrol., Apr. 11.

Наталья Савельева-Кулик 